\title{
Funding forces fusion project out of Europe
}

Munich. The International Thermonuclear Experimental Reactor (ITER), a multibillion dollar project to assess the feasibility of controlled nuclear fusion, will almost certainly not be built in Europe. This follows a joint announcement last week by the French and German research ministers that they are withdrawing their interest in offering sites for ITER, as the projected costs for the host country had risen too high.

The ministers expressed continued support for ITER and for fusion research in general. But their announcement throws into further doubt the future of a project that has already suffered a series of blows over the past year, particularly a decision by the United States to pull back sharply from its commitment to fusion research (see Nature 379, 387; 1996).

Nevertheless, the Franco-German announcement came as a surprise to both fusion scientists and ITER administrators, as bids for the siting of the reactor are not yet due. ITER is in the middle of a six-year engineering design phase, scheduled for completion by 1998 . A decision on where it should be built is not required until the end of next year, while negotiations on costsharing will begin in the next 12 months.

Given the current stage of discussions, Klaus Pinkau, director of the Max Planck Institute for Plasma Physics in Garching, says he was "astonished". It was a mistake for Germany and France "to show their cards before negotiations have started".

The German and French ministries of research declined to comment on the timing of their joint announcement. But it is widely believed to have been taken as a result of pressures in both countries to reduce future expenditure in order to meet the 'Maastricht' criteria for joining the planned single European currency.

ITER is a joint venture of the European Union (EU), Japan, the United States and Russia. Problems with financing have arisen partly because Russia and the United States have said that they are no longer in a position to make the level of contribution envisaged when the project was conceived in the mid-1980s. As a result, the EU and Japan would have to pay a much greater percentage of the costs to host ITER, whose total bill will probably exceed US $\$ 15$ billion.

In an informal proposal to the ITER management earlier this year, Japan raised the stakes by saying that it would be prepared to pay all the basic costs of the project, if the reactor were to be built in Japan (see Nature 380, 655; 1996). It envisaged that the remaining costs, the so-called 'high-tech core', which it estimated at 40 per cent of the total, would then be split equally between the four partners. This would mean Japan paying 70 per cent of the total.

At the beginning of May, the European Commission (EC) distributed to EU member states a paper intended to help them prepare proposals for hosting the reactor. Germany was expected to propose a site at Greifswald, where its next-generation fusion machine, Wendelstein $7 \mathrm{X}$, is being built. France was expected to propose a site at Cadarache, where the Commissariat à l'Energie Atomique (CEA) has its fusion facility.

Europe would like the shared high-tech

\section{Russian contribution for CERN collider}
Moscow. Russia's parti- cipation in the planned \$3-billion Large Hadron Collider project (LHC) at the European Labora- tory for Particle Phys- ics (CERN) in Geneva has been confirmed in a decree published by the government last month. The government has agreed to contribute US\$60 million towards the design and construction of the LHC. In addition, 430 Russian scientists will work on the ATLAS, CMS and ALICE experiments.

Russia has already completed the first of 65 modules for a hadron calorimeter for the ATLAS experiment on colliding proton beams. Scientists at the Joint Institute for Nuclear core costs to be much higher than that suggested by Japan, namely 70 per cent of the total. So the EC paper suggests that the total cost to the host country should lie between its own estimate of 47.5 per cent and the Japanese estimate of 70 per cent. The Franco-German statement, which was a response to this paper, does not indicate whether the two countries would be prepared to reconsider their withdrawal should the cost to the host country end up, after negotiations in the next two years, at the lower end of this scale.

Ernesto Canobbio, a commission official with responsibility for the ITER project, says that the timing of the statement is particularly surprising, as it also pre-empts the report of an independent committee set up by the commission to assess the international fusion programme. That committee's report is due later this year. Sergio Barabaschi, an industrial scientist and adviser on science to the Italian government who is the chairman of the committee, says that the timing of the Franco-German statement "does not follow any logic".

But Canobbio points out that early knowledge of France and Germany's decision makes life simpler. "At least we don't have to keep alive a fiction," he says. He now plans to negotiate the best possible deal for European researchers - assuming that the reactor will indeed be built elsewhere. Japan is now the only realistic option.

Pinkau says that the most important thing now is for ITER to go ahead "because it is the main thrust of all fusion research". Michel Chatelier, deputy head of the CEA Department of Controlled Fusion in Cadarache, says that scientists have always been aware that the high cost of ITER makes it vulnerable. He is relieved that the Franco-German statement signalled strong support for fusion research in general.

Alison Abbott

\section{Budget for US physics}

Washington. Appropriations committees of both the US Senate and House of Representatives have passed 1997 spending proposals for the Department of Energy that would maintain most physics research programmes just above this year's levels.

There are slight reductions for magnetic fusion research, to which the House proposes allocating $\$ 209$ million and the Senate \$225 million in 1997, compared to this year's spending of $\mathbf{\$ 2 2 7}$ million and the president's request of $\$ 264$ million. The House is also calling for drastic reductions in administrative spending at the department, including cuts of two-thirds in the public and congressional relations department, and seven out of eight members of the policy staff. 